\title{
ロボット機構系の設計 ${ }^{*}$
}

\author{
高 野 政 晴**
}

\section{1. 序 論}

産業用ロボットの生産は年間 4 万台を越えているので あるから をしているには違いない，しかし果して誰れるが納得で きるような合理的な設計をしているだろらか．というの は図1に見られるように，現在の産業用ロボットは可搬 重量に対して本体重量が重すぎるといら素朴な疑問が捨 て切れないからである. 人間の腕は強度が小さく柔い有 機物で作られているにも拘らず自重の $10 \%$ 位のワーク を扱うことができるのに，金属で作られているロボット が何故人間上り能力が劣るのだろらか. 人間には感覚と 頭脳があるとか，又ロボットは軽ければよいというもの ではないとか，いろいろ理由があるだろらが，それにし てもロボットがあらゆる条件を考慮して設計されている とは思えない。

さてロボットに限らず一般に設計問題とは，設計パラ

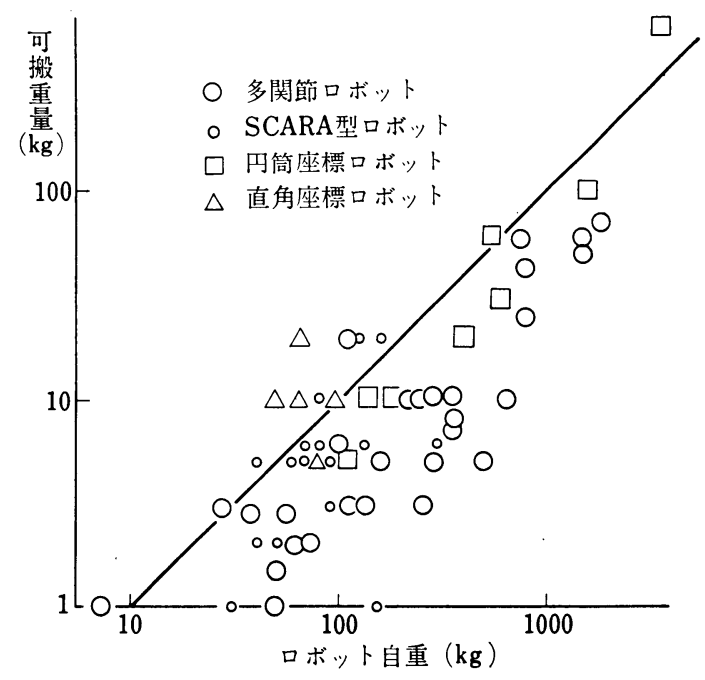

図1産業用ロボットの自重と可搬重量の関係 （代表的な数社のメーカのカタログによる）

原稿受付 1986 年 4 月 18 日

* Design of Robot Mechanical System

** 東京大学工学部
メータがありそ関数として拘束条件と評価関数が与 えられ，拘束条件の範囲内で評価関数を最大に（または 最小に）するパラメータの值を求めるといらことである. ロボットの場合その関数関係が極めて複雑であるかある いは表現できないか，評価そのものもはっきりしないか， とにかく設計者の直観に頼らざるを得ないことが多い， 直観は経験から生れる。ロボットが世に現れて以来寸法 のバランスがあまり変化していないのもやむを得ないか も知れない，しかし将来生産工場だけでなくオフィス， 家庭，病院，その他人間が生活の場としているいろいる な環境にロボットが入ってくることを考光ると、ロボッ トは人間に恐怖心を与充ない程度にスマートでなければ ならない，そのためにはロボットの設計の方法とその問 題点を明らかにして拈く必要がある。ここでは，ロボッ トの設計パラメータ，設計の評価関数と拘束条件などを 明らかにし，いくつかの最適設計の研究例と筆者が考兄 ている設計システムについて述べる.

\section{2. 設計パラメータと評価関数}

設計パラメータはロボットの基本機構と内部機構に分 けることができ，それぞれ次の項目が考えられる。

\section{基本機構}

1) 自由度

2) 関節の種類 (回転か直動か)

3） アーム長とオフセット（より一般的には隣り合う 関節の位置関係）

内部機構

1） アーム太さなどの形状

2) モータの取付け位直（モータの直接配置か間接配 置か)

3）层達機構（関節部の機構，チェイン，ワイヤ，同 心軸, 歯車など)

4) 減速機と減速比

5）モータの種類（電気，油圧，空圧）

6）重力バランサの有無

7）ブレーキその他の付属部品

8）軸，軸受などの機械要素 


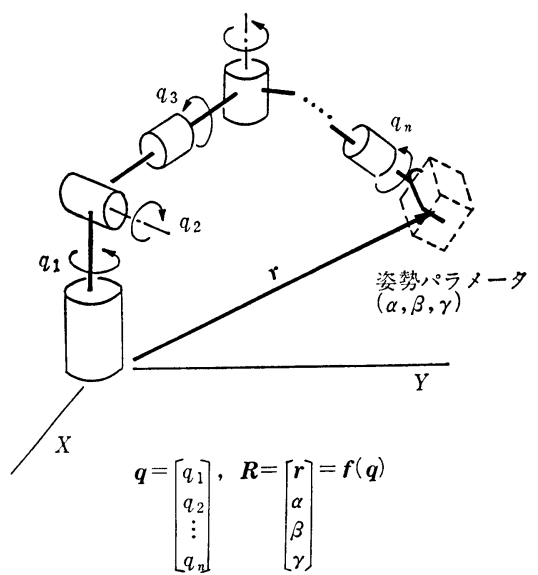

(a)関節变位とワークの位置姿勢
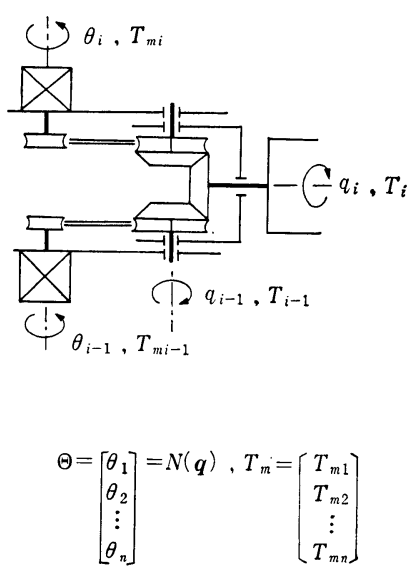

(b) 関節変位とモータ変位

図 2 運動学的解析

基本機構は主としてロボットの運動学的性質に関連し ているのに対し，内部機構は主としてロボットの力学的 性質に関連している. 一方ロボットの評価の対象として 次のものが考兄らる.

1）作業のし易さ（a）

2) モータパワーの総和 (b)

3) アーム重量 (b)

4) ロボットの全重量 (b)

5) コスト (a, b)

6) 作業空間の広さ（a）

7) 可搬重量 (b)

8）関節変位の上下限 (a)

9）エンドェフェクタの速度加速度の最大值（a )

10）静たわみ（b）

11) 固有振動数 (b)

12）精度（くり返し精度, 絶対精度)（a， b)

後につけた（a)，（b）はそれぞれ運動学，力学に関係 することを示す．これらの評価対象は設計の際の拘束条
件にも評価関数にもなり得る. 一般的には 6)〜12) の項 目はロボットの仕様として与えられるべきもの，すなわ ち設計の拘束条件であり，1＜wide>５）は同じ性能を持つ口 ボットがあった場合にそのよしあしを決める因子，すな わち評価関数となるべきものである．1）の作業のし易 さとはあいまいな表現であるが，まだ確定的な尺度はな い. 提案されているものの一つに吉川が提案した「可操 作度 (manipulability) 」) あるいはアームの慣性も考慮 した「動的可操作度」3) がある. 可操作度は関節駆動速 度とアーム先端の移動速度の比に相当するもので, 可操 度が大きいといらことは運動学的に先端速度を上げられ ることを意味する.作業空間全体で可操作度が大きくか つばらつきができるだけ小さいということが作業し易さ の一つの尺度になり得る.これとやや異る観点であるが Fenton ら (4) 数多くのワークのパスについて関節变位 の総和が最も少くなるようなアーム長の最適設計を試み ている. 動かし易さの意味では可操作度は有力な尺度で あるが，力作業の場合は力の伝達度の大きい方がよく，

表 1 設計パラメータと評価関数 (左欄), 拘束条件 (右欄) との関係の深さ 拘束条件はロボットの仕椂に対応するが, 評価関数と相互に代り得る.

\begin{tabular}{|c|c|c|c|c|c|c|c|c|c|c|c|c|c|}
\hline & $\begin{array}{l}\text { 拘束または } \\
\text { 評価関数 } \\
\end{array}$ & 㩰作度 & $\begin{array}{l}\text { 全 } \\
\text { パワー }\end{array}$ & $\begin{array}{l}\text { アーム } \\
\text { 重 舅 }\end{array}$ & 全西量 & コスト & $\begin{array}{ll}\text { 作 } & \text { 潾 } \\
\text { 空 } & \text { 間 }\end{array}$ & $\begin{array}{ll}\text { 可 } & \text { 搬 } \\
\text { 正 } & \text { 量 }\end{array}$ & 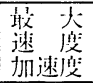 & $\begin{array}{l}\text { 関筇変 } \\
\text { 位限界 }\end{array}$ & 撓 み & $\begin{array}{ll}\text { 娄 } & \text { 有 } \\
\text { 振動数 }\end{array}$ & 精 度 \\
\hline 基 & 自 由 度: & (2) & 0 & 0 & 0 & () & () & $\Delta$ & $\Delta$ & $\triangle$ & 0 & 0 & 0 \\
\hline 本 & 関 節 種 類 & (a) & 0 & 0 & 0 & () & () & $\Delta$ & $\Delta$ & 0 & 0 & 0 & 0 \\
\hline 機 & ア - ム 長 & (C) & (a) & (C) & (C) & 0 & (a) & () & (C) & $\triangle$ & (a) & (a) & (a) \\
\hline 構 & オフセット & (C) & $\triangle$ & $\Delta$ & $\Delta$ & $\Delta$ & (2) & 0 & $\triangle$ & (a) & $\Delta$ & $\triangle$ & $\triangle$ \\
\hline 内 & モータ配誼 & $\triangle$ & (a) & (a) & (a) & $\Delta$ & $\Delta$ & (a) & $\Delta$ & $\triangle$ & $\Delta$ & $\Delta$ & $\Delta$ \\
\hline 部 & 伝 動 機 構 & $\Delta$ & $\Delta$ & () & (C) & (O) & $\Delta$ & $\Delta$ & $\Delta$ & (a) & (2) & () & () \\
\hline 機 & 減 速 & $\Delta$ & (a) & (a) & (2) & (C) & $\Delta$ & (C) & (2) & $\triangle$ & (a) & (a) & (2) \\
\hline 構 & - & $\Delta$ & (a) & () & ()) & ()) & $\Delta$ & ()) & ()) & $\Delta$ & $\triangle$ & $\Delta$ & $\Delta$ \\
\hline
\end{tabular}




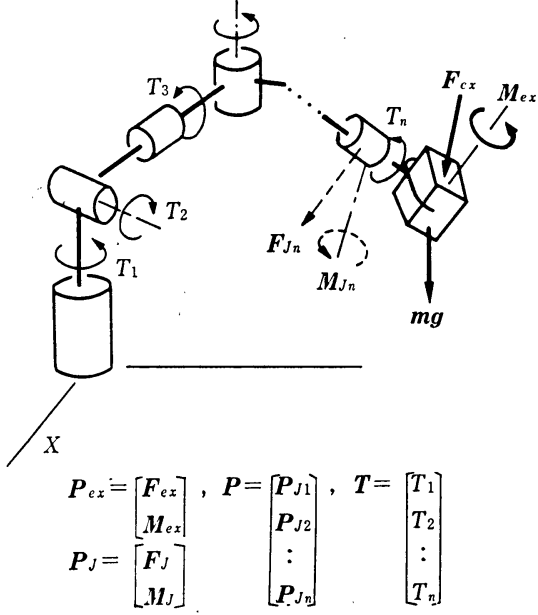

（a）外力・動的力と関節に加わる力

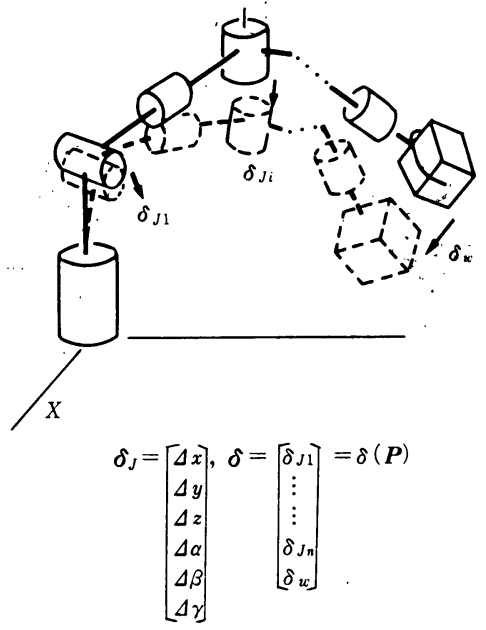

（b）関節に加わる力による関節・ワークの撓み 力学的解析
その伝達度は可操作度の逆数になる. すなわち可操作度 は小さい方がよく，目的によって評価が全く逆になる.

表 1 は設計パラメータと評価関数あるいは拘束条件 との関連の深さを示している.この表から明らかなこと は基本機構は運動学的評価（拘束）関数に，内部機構は 力学的評価 (拘束) 関数に深い関係があるといら事実で ある.このことは基本機構設計と内部機構設計をそれぞ れ独立に行っても大きな間違いはないことを示唆してい る.

\section{3. ロボットシミュレーション}

設計パラメータを与えて前記の拘束条件と評価関数は 運動学的および力学的演算をすることによって求めるこ とができる. 設計のために計算すべき事項は次の通りで ある.（記号については図 2,3参照）

運動学的計算 (図 2)

1) 順運動学: $R=\boldsymbol{f}(\boldsymbol{q})$

2) ヤュビアン行列 $: J=\partial \boldsymbol{R} / \partial \boldsymbol{q}$

3) 速度 - 加速度解析 : $\dot{\boldsymbol{R}}=J \dot{\boldsymbol{q}}, \dot{\boldsymbol{R}}=J \ddot{\boldsymbol{q}}+D(\boldsymbol{q}, \dot{\boldsymbol{q}})$

4) 逆運動学 : $q=f^{-1}(R)$, および

$$
\dot{\boldsymbol{q}}=J^{-1} \dot{\boldsymbol{R}}, \ddot{\boldsymbol{q}}=J^{-1}\{\ddot{\boldsymbol{R}}-D(\boldsymbol{q}, \dot{\boldsymbol{q}})\}
$$

5）関節変位速度加速度からモータの变位速度加速へ の変換

$$
\begin{aligned}
& \boldsymbol{\theta}=N(\boldsymbol{q}), \dot{\boldsymbol{\theta}}=\partial N / \partial \boldsymbol{q} \cdot \dot{\boldsymbol{q}}, \\
& \ddot{\boldsymbol{\theta}}=\partial N / \partial \boldsymbol{q} \cdot \ddot{\boldsymbol{q}}+N_{1}(\boldsymbol{q}, \ddot{\boldsymbol{q}})
\end{aligned}
$$

力学的計算 (図 3)

1）静力学：自重・外力によるアーム・関節に加わる

$$
\text { 一カとモーメント … } \boldsymbol{P}=\boldsymbol{P}\left(\boldsymbol{q}, \boldsymbol{P}_{\mathrm{ex}}, \boldsymbol{g}\right)
$$

2) 動力学：運動によって生ずる動的力・モーメント
によるアーム・関節に加わる力・モーメント

$$
\boldsymbol{P}=\boldsymbol{P}\left(\boldsymbol{q}, \dot{\boldsymbol{q}}, \ddot{\boldsymbol{q}}, \boldsymbol{P}_{\mathrm{ex}}, \boldsymbol{g}\right)
$$

3）モータ負荷 : 関節駆動トルクとモータトルクの変 換, モータパワー

$$
\boldsymbol{T}_{m}=(\partial N / \partial \boldsymbol{q})^{-1} \cdot \boldsymbol{T}, \quad \boldsymbol{H}_{m}=\boldsymbol{T} \cdot \dot{\boldsymbol{q}}
$$

4) 撓み解析 : $\boldsymbol{\delta}=\delta(\boldsymbol{P})$

5) 振動解析: $M(\boldsymbol{q}) \ddot{\boldsymbol{d}}+K(\boldsymbol{q}) \boldsymbol{d}=0$,

$$
\left|K(\boldsymbol{q})-M(\boldsymbol{q}) \omega_{i}{ }^{2}\right|=0,=1,2, \cdots
$$

自由度が高い場合にはこれらの計算はどれも手ででき るものではない，まして全ての計算を行ならとなれば計 算機に頼らざるを得ない.このように設計には上記の解 析を行ない評価データを与えるロボットシミュレータが 必要となる. ロボットシミュレータは世界各国で数多く 開発されているが，設計の目的の汎用シミュレータはま だ少い. そのらちでも Liégeois ${ }^{5)}$, Warnecke ${ }^{6)}$, Vukobratovic ${ }^{7)}$ のシステムが注目される.

\section{4. 最適設計の試み}

部分的にある設計パラメータを変えて一つの評価関数 を最大 (最小) にする研究がいくつか発表されている. Yang $ら^{8)}$ は作業空間を最適化する目的で正規化体積指 数 NVI なるものを導入した. これは作業空間体積の全 アーム長を半径とする球体積に対する比で, 各アームの 長さや関節変位の限界, マニピュレータの剛性などを拘 束条件として NVI を最大にするアーム長比を heuristic に見出す手法を提案している．この試みによると人間の 上腕と前腕の比は作業空間が広いといら意味で最適であ るとのことである. そのほか PUMA 600, Pana-Robo 
についても最適アーム比を求めている. Vukobratovic らのははロホットの撓み, 強度, モータパワーとトルクを 拘束条件とし，ワークを搬送する作業でロボットの動力 学的考慮をしながら作業時間を最小にするためのアーム の太さとモータ減速比を求めている. ただしそれぞれ独 立に最適化されており, 結果として最適であるとは限ら ない.この著者らはほかにも消費パワーの最適化 ${ }^{10) や ， ~}$ 会話形式でモータ, 減速比, アーム太さを決定するシス

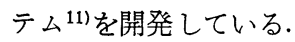

これらの設計例ではロボットの基本構造が決定され, 駆動モータも取付け位置が決まっているものとしてアー ム長, 太さ, モータパワーなどの最適值を見出す問題を 扱っている. 基本機構と内部機構がどうあるべきかは, 機構の選択が離散的 (回転関節か直動関節か, 歯車伝動 かチェイン伝動かなど）で評価関数や拘束条件との関係 を記述できないので，まだ部分的にも試みられた例はな い. これからも部分的な最適化の試みが研究されると思 らが，その部分的最適設計が全体の設計の中でどのよう な意味を持っているかその位置づけと利用可能性を考慮 しつつ設計パラメータと評価関数の関係を作り上げてい く必要があろう.

\section{5. 設計システムの構想}

ロボットの設計システムには, 既にあらゆる機構が決 っていて単に寸法やモータの能力を変更するだけの設計 と, 機構の選択をも含む総括的な設計とがある. 前者は 比較的簡単であり，たとえば SCARA 型組立用ロボット の仕様変更による諸元の変更の計算機援用設計 (CAD と CAM を含めて) システムはロボットメーカがそのつ もりがあれば今すぐにでも開発できるであろら．この諸 元変更の設計システムは総括的設計システムのところど ころにらりばめられるのでここでは後者の総括的設計シ ステムについて述べ，実現のため今後の問題点を併せて 論ずる.

図 4 はロボットに要求する作業を入力して, 目的に適 ら最適なロボットの機構・寸法・選択した部品を決定す る手順を示している ${ }^{12)}$.

はじめにロボットの作業入力データ（ワーク重量, 動 作形態, 時間, 精度など) からロボットの仕様（第 2 章 7）および 9)～12）の拘束条件）を決める. この場合口 ボットの融通性をメリットとする以上, 入力した作業を 特定な条件下で果すだけでは不十分であり，作業の性質 を考慮して作業空間内のどこででも動作が可能であるこ とが必要とされる．入力作業から作業空間や，ロボット のカタログ上には記載されていない撓みや固有振動数を どのように設定するかは今後の問題である. 次のパート
の基本機構設計では運動学的考慮のもとに運動学的評価 関数を最適にする機構 (自由度, 関節種類) の選択とア 一ム基本寸法の決定を行なう. 前述のように運動学的評 価は基本機構に, 力学的評価は内部機構に深い関係があ るので，各設計の段階でそれぞれの評価関数を最適にす ることで全体が最適になるだろらといら考学が背景にあ る.またこれによって部分的な最適設計の手法もこのシ ステムにそのまま応用できるというメリットもある. こ の基本機構設計でアーム長とオフセットは量的に評価関 数に組込むことができるが, 関節種類とその順番は現在

(1)

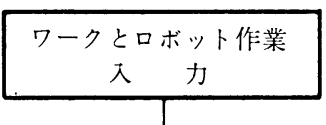

(2)
基
機
構
設
计

口ボットの仕様決定
(設計の拘束条件)

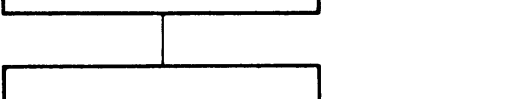

ロボットの基本構遥設計

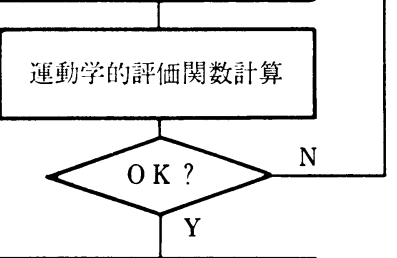

(3)

内
部
機
構
概
略
設
棓

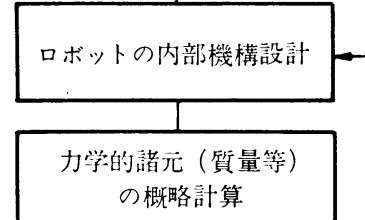

力学的評価関数㢵算

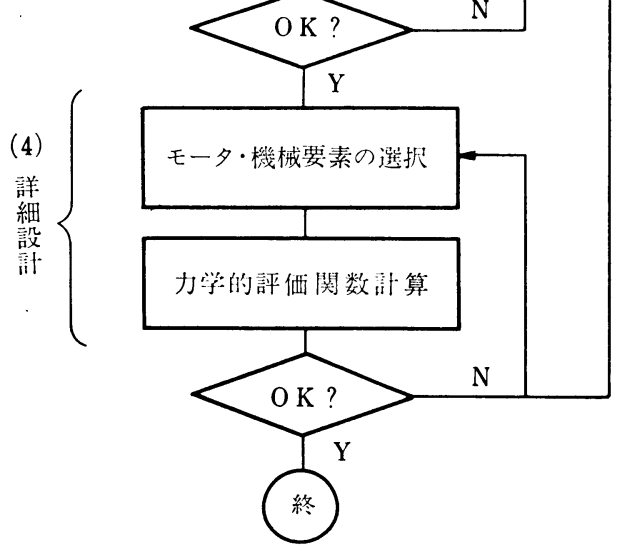

図 4 ロボットの一般的な設計手順 


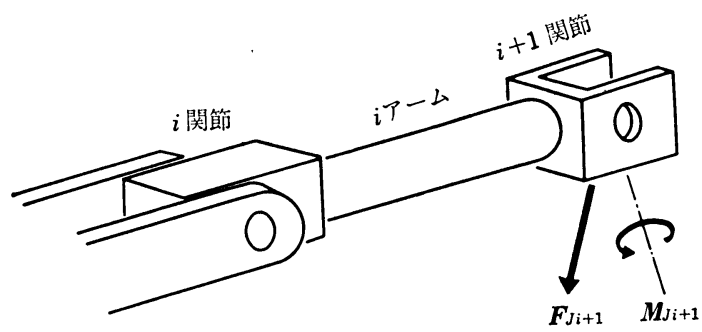

図 5 アーム・関節の諸元の backward recursive な概略計算

$\boldsymbol{F}_{J i+1}, \boldsymbol{M}_{J i+1}: n \sim(i+1)$ までのアーム関節の動的 カモーメントの和の最大値・ $\boldsymbol{F}_{J i+1}, \boldsymbol{M}_{J i+1}$ から許容 撓み以下となる $i$ アームの寸法・重量・憤性モーメン トの概略值が計算され，i アームの動的力を更に加え て関節の寸法等の概略值が計算される.

のところ評価を与える適当な表現方法がない，ただしと り得る場合の数は有限であるから全てを試してみるとい ら方法もある. ロボットの設計者は経験的にどの作業に はどのタイプのロボットがよいといらことを知っている. この経験を設計システムのデータとして蓄えておくのも 一つの方法である.

ロボットの基本機構と関節変位の限界から作業空間を 求める一般的方法が数多〈研究されている ${ }^{13)}$. 一般的な ロボットの作業空間の輪郭とその体積を求める計算は時 間がかかるが，ロボットのタイプが与えられれば人が見 てどうすれば早く計算できるかは一目膫然である。この 求め方を人に頼ることも一つの方法であろう. 作業し易 さの尺度として可操作度の評価を作業空間全域でするの も大変に時間がかかる. 自由度, 関節種類, アーム長の パラメータを变えて最適化を図ることは不可能に近い.

もっと簡易的な評価方法が望まれる.

次は力学的考虑のもとに力学的評価関数を最適にする 内部機構の選択と詳細寸法を決定するパートである.こ の評価関数はいくつかあるが，一般的に言えばそれらの 線形和として全体の評価関数を作り, 各々の重みは作業 の性質から決めるべきである.この設計においても内部 機構 (モータをどこにおくか, ぞの伝達機構を使らか) の選択の決め手はない，定性的には次のことが言える. モータを駆動すべき関節部からべースに近い方へ持って いけば， アーム・関節の負担が小さくなり軽量化が可能 になるとともにモータパワーも小さくてすむが， その代 ク，伝達機構が必要になり，ロボットの剛性が小さくな る. また自由度が大きいとべース近くのモータまで多く の関節を通り抜けねばならず, 機構が複雑になり, 歯車 などを使用するとかえって重量が増す。

さて，力学的考慮のもとに内部機構をきめて具体的な 寸法を決定する手順を，概略設計と詳細設計に分けると

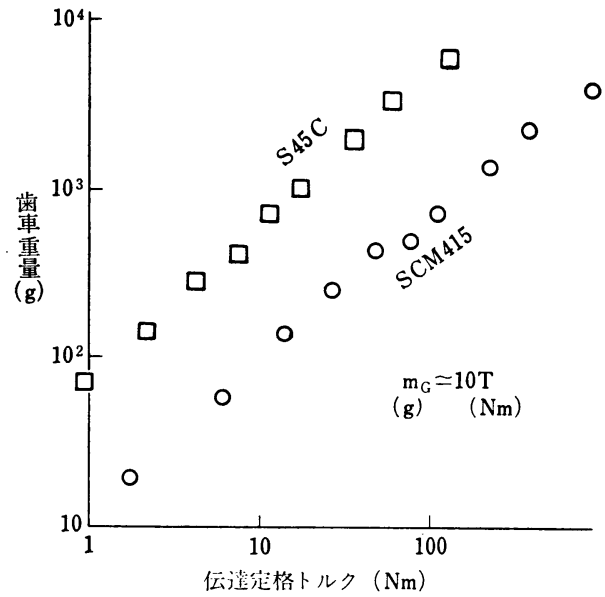

図 6 かさ歯車のトルクと重量の関係

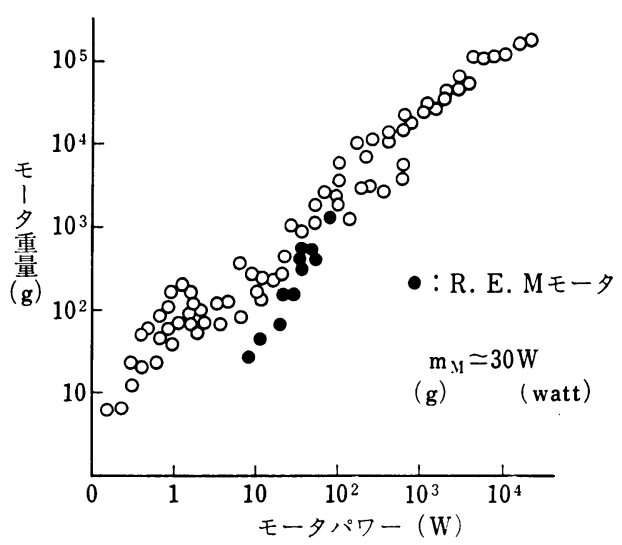

図 $7 \mathrm{DC}$ サーボモータのパワーと重量の関係

便利である. 概略設計では図 5 のよらに運動から計算さ れるアーム関節に加わるカ・トルクの最大值に対し, 撓 みを各アーム関節毎に許容值以下になるように太さ・大 きさを計算する.この諸元からアーム関節の概略重量が 決まる. また质達機構に加わる力・トルクもわかるので その機構の大きさと重量が決まる. 伝達機構の許容值と 重量の関係は製品データから例觉ば図 6 の上うに与兄 られる. 関節の駆動力（トルク）と速度の積の最大值か らモータのパワーが決まりモータの重量む図 7 の製品 データの関係から決まる.

先端のアーム関節からべースへと順にこの計算をし評 価関数のアーム重量, ベースも含む全重量, 全モータパ ワーが求まる. この概略設計の段階で評価関数（の線形 和）の最適化を試みる.

詳細設計では，力学的計算からアーム関節の具体的な 寸法を決め, 機構部品やモータ, 減速機と減速比を選択 する．減速比は機械インピーダンスマッチング(4)，位置 
決め精度, 分解能から決める. 改めて撓み解析, 振動解 析, 精度解析を行ない, 要求仕様を満足しているかどら か調べる.この計算において問題なのは伝達機構と機械 要素の剛性が明らかでないことである.たと兊ば歯車の

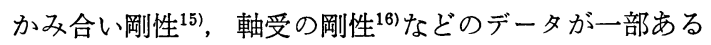
が, あらゆる種類のるのについて信頼できる剛性のデー タはまだない.

力学的な評価関数はロボットの重量, モータパワー, あるいはその線形和であり，概略設計で最適化を試みて おけば詳細設計でも大幅に変更することはない筈である. 図 8 は我々の研究室で開発中の沉用ロボット設計シス

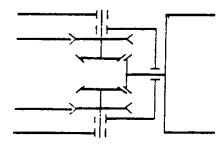

(a) $J_{4} J_{5}=\mathrm{PR}$

PR-P-N-2 B

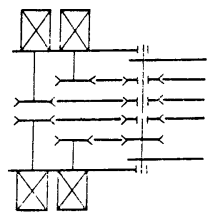

(c) $J_{2}=\mathrm{P}$

$\mathrm{P}-\mathrm{P}-3 \mathrm{P}-4 \mathrm{I}$

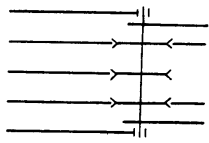

(b) $J_{3}=\mathrm{P}$ P-P-2 P-3 B

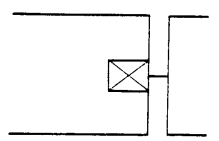

(d) $J_{1}=\mathrm{R}$

$\mathrm{R}-\mathrm{R}-\mathrm{N}-\mathrm{D}$

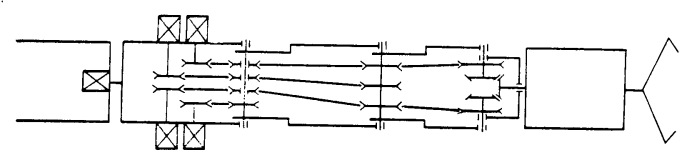

（e）設計された内部機構全体図

图 85 自由度 RPPPR 多関節ロボットのモータ 間接配置の設計例 (TO-CARD に上る)

(a)
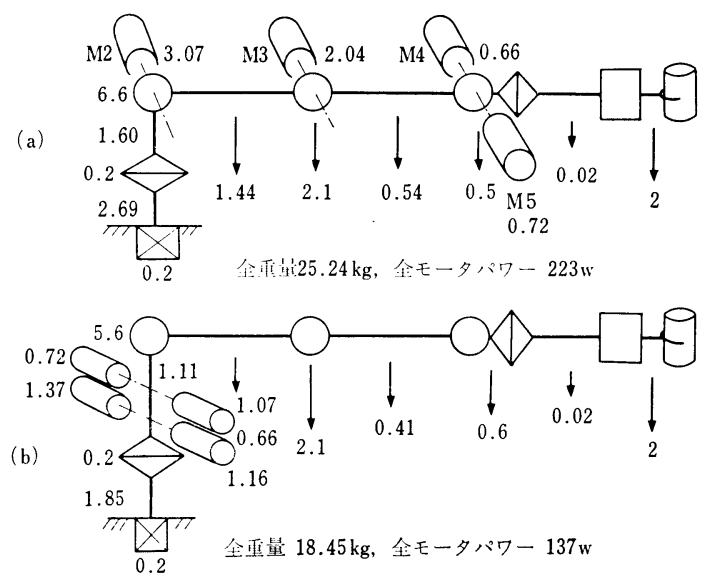

図 9 モータ直接配置 (a) と間接配置 (b)

の重量・パワーの概略見積り

図中の数字は各部の重量 $(\mathrm{kg})$ を示す.
テム“TO-CARD”を利用し，会話形式により 5 自由度 のRPPPR 多関節ロボットの内部機構設計を行なったそ 出力を示す. 図 9 はロボット全重量を評価関数とし、モ 一夕を直接配置した場合と間接配置した場合の出力例, 図 10 はある軌道について動力学計算し, 詳細設計をく り返したときの結果の収束性を示す．ただしここでは固 有振動数の計算は行なっていない.

これらの設計に执いてオペレータの経験が多く関与し ている. 結果の妥当性もオペレータの判断による.この ようにロボットの設計のために単に計算の手間を省いて くれる以上の能力を計算機に要求するのはまだ当分無理 のよらである.

\section{6. 結 論}

ロボットマニピュレータを設計するその設計パラメー タと拘束条件, 評価関数を明らかにし, それらの間の関 係深さについて述べた. しかし設計パラメータの全てに ついて量的な関係を求めることは難しく, 将来 CAD シ ステムを開発するにしても専門家の知識を大幅に利用す るものにならざるを得ないであろう. 現在研究対象が口 ボットの基本機構に関するものが多いが, 同じ性能を持

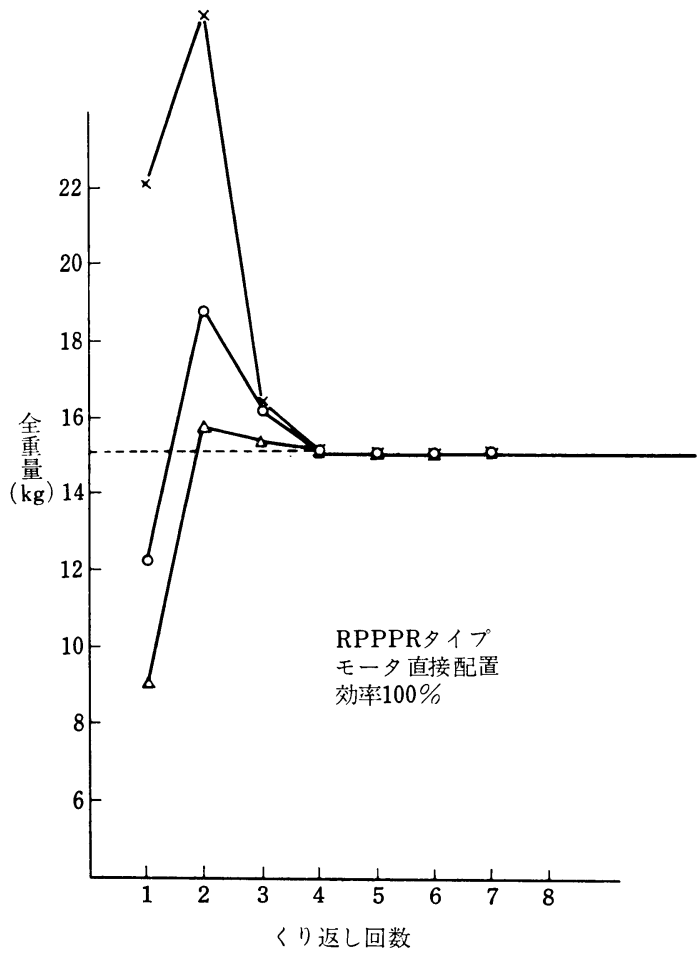

図 10 詳細設計を任意の初期設計からくり返した ときの設計解の収束の様子 
つロボットの良否は内部機構設計で決まることを銘記し て技くべきである. 最適設計の試みもかなりされている が現在はまだ研究のための研究の域を脱していない.動 力学演算や撓み計算はやむを得ないとしても作業し易さ や固有振動数の尺度をもっと簡単なものに置換えられれ ば CAD システムが実用化されるであろう. 我々のシ ステム TO-CARD ではオペレータが評価する方向で開 発を進めている.

CAD システムはもちろんここで述べた方法が唯一無 二ではない. 別の考え方の総括的ロボット設計システム が特にメーカサイドから提案されることを望みたい。

\section{参考 文 献}

1）JIRA：産業用ロボット企業実態調査報告, ロボット, 48, pp. $20-23,1985$

2) Tsuneo Yoshikawa: Manipulability of robotic mechanisms, Proc. 2 nd ISRR, pp. 439-446, 1984

3）吉川恒夫：ロボット的機構の動的可操作性，日本ロボッ 卜学会第 2 回学術講演会予稿集, pp. 199-200, 1984

4) R.G. Fenton and J. Lipitkas : Optimum design of manipulators, Comp.-Aided Eng. and Robotics, pp. 68-73, 1984

5) A. Liégeois 他: A system for computer-aided design of robots and manipulators, Proc. 10 th ISIR, pp. 441 $-452,1980$

6) H.-J. Warnecke and M.-C. Wanner : Entwicklung und Anwendung rechnergestützte Konstruktionshilfen zur Auslegung von Roboterstrukturen, Robotersysteme, 1, pp. 75-82, 1985

7) M. Vukobratovic 他: General software for manipulation robots, special issue from Mihailo Pupin Institute, 1982

8) D. C. H. Yang \& T. W. Lee : Heuristic combinational optimization in the design of manipulator workspace, IEEE SMC-14, 4, pp.571-80, 1984

9) V. Potkonjak \& M. Vukobratovic : Computer-aided design of manipulation robots via multi-parameter optimization, Mechanism and Machine Theory, 18, 6, pp. 431-438, 1983

10) M. Vukobratovic 他: Computer-aided choice of electro hydraulic actuators for manipulation robots, Proc. 14 th ISIR, pp. 711-721, 1984

11） V. Potkonjak 他: Interactive procedure for compu ter-aided design of industrial robots mechanisms, Proc. 13 th ISIR, pp. 16-85-94, 1983

12) M. Takano 他: Concept of total computer-aided design system of robot manipulators, Proc. $3 \mathrm{rd}$ ISRR, pp. 142-149, 1985

13）たとえぱ M. Cwiakala \& T. W. Lee : Generation and evaluation of a manipulator workspace based on optimum path search, Paper ASME[84-DET-185], pp. 1122-1-11, 1984

14）高野政晴：ロボットの運動の高速化技術，計測と制御， 21, 12, pp. 1122-1128, 1983

15）梅沢清彦：歯車の振動 とその制御, 日本機械学会誌, 88, 805, pp. $1377-1382,1985$

16）上都喬史：ロボット用軸受，設計製図 $20 ， 120$, pp. 204 $-209,1985$

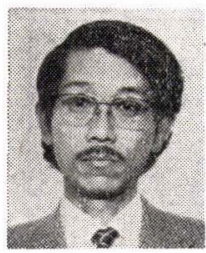

高野政晴 (Masaharu TAKANO)

昭和11年11月生れ. 35年東京大学工学部 精密工学科卒業. 工学博士. 38年同学科助 手を経て55年より同教授，現在に到る、こ の間, 機械振動, 騒音, 機構の動力学, 口 ボットの運動と制御の研究に従事. 61年精 密工学会沼田記念賞受賞. 精密工学会, 日 本機械学会などの会員. 